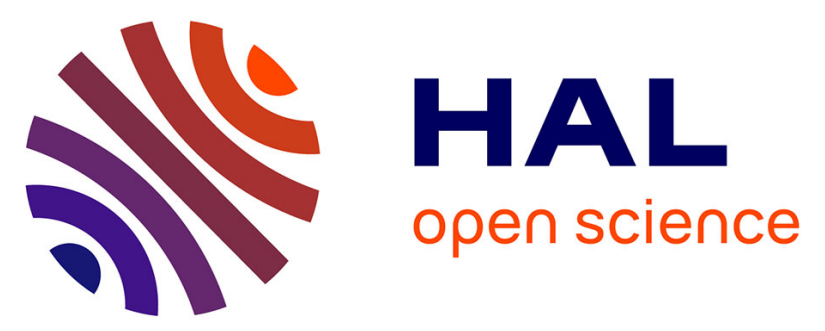

\title{
Use of response surface methodology to optimise environmental stress conditions on Penicillium glabrum, a food spoilage mould
}

Laurent Nevarez, Valérie Vasseur, Stella Debaets, Georges Barbier

\section{- To cite this version:}

Laurent Nevarez, Valérie Vasseur, Stella Debaets, Georges Barbier. Use of response surface methodology to optimise environmental stress conditions on Penicillium glabrum, a food spoilage mould. Fungal Biology, 2010, 114 (5-6), pp.490-497. 10.1016/j.funbio.2010.03.011 . hal-00551280

\section{HAL Id: hal-00551280 \\ https://hal.univ-brest.fr/hal-00551280}

Submitted on 3 Jan 2011

HAL is a multi-disciplinary open access archive for the deposit and dissemination of scientific research documents, whether they are published or not. The documents may come from teaching and research institutions in France or abroad, or from public or private research centers.
L'archive ouverte pluridisciplinaire HAL, est destinée au dépôt et à la diffusion de documents scientifiques de niveau recherche, publiés ou non, émanant des établissements d'enseignement et de recherche français ou étrangers, des laboratoires publics ou privés. 
1 Use of response surface methodology to optimise environmental stress conditions on

2 Penicillium glabrum, a food spoilage mould

3

4 Laurent Nevarez, Valérie Vasseur*, Stella Debaets, Georges Barbier

6 -Université Européenne de Bretagne, France

7 -Université de Brest, EA3882 Laboratoire Universitaire de Biodiversité et Ecologie Microbienne, 8 IFR148 ScInBioS, ESMISAB, Technopôle de Brest Iroise, 29280 Plouzané, France

$10{ }^{*}$ Corresponding author. Phone: +3329805 61 00; Fax: +33298056101

11 E-mail address: valerie.vasseur@univ-brest.fr

\section{ABSTRACT}

14 Fungi are ubiquitous micro-organisms often associated with spoilage and biodeterioration of a large

15 variety of foods and feedstuffs. Their growth may be influenced by temporary changes in intrinsic 16 or environmental factors such as temperature, water activity, $\mathrm{pH}$, preservatives, atmosphere 17 composition, all of which may represent potential sources of stress. Molecular-based analyses of 18 their physiological responses to environmental conditions would help to better manage the risk of 19 alteration and potential toxicity of food products. However, before investigating molecular stress 20 responses, appropriate experimental stress conditions must be precisely defined. Penicillium 21 glabrum is a filamentous fungus widely present in the environment and frequently isolated in the 22 food processing industry as a contaminant of numerous products. Using response surface 23 methodology, the present study evaluated the influence of two environmental factors (temperature 24 and $\mathrm{pH}$ ) on $P$. glabrum growth to determine 'optimised' environmental stress conditions. For 25 thermal and $\mathrm{pH}$ shocks, a large range of conditions was applied by varying factor intensity and 26 exposure time according to a two-factorial central composite design. Temperature and exposure 
27 duration varied from 30 to $50^{\circ} \mathrm{C}$ and from $10 \mathrm{~min}$ to $230 \mathrm{~min}$, respectively. The effects of

28 interaction between both variables were observed on fungal growth. For $\mathrm{pH}$, the duration of

29 exposure, from 10 to $230 \mathrm{~min}$, had no significant effect on fungal growth. Experiments were thus

30 carried out on a range of $\mathrm{pH}$ from 0.15 to 12.50 for a single exposure time of $240 \mathrm{~min}$. Based on

31 fungal growth results, a thermal shock of $120 \mathrm{~min}$ at $40^{\circ} \mathrm{C}$ or a $\mathrm{pH}$ shock of $240 \mathrm{~min}$ at 1.50 or 9.00

32 may therefore be useful to investigate stress responses to non-optimal conditions.

34 Keywords: Penicillium glabrum, food spoilage, thermal shock, acid shock, alkali shock, mycelial 35 growth, response surface methodology, central composite design.

\section{Introduction}

37 Fungi are ubiquitous micro-organisms often associated with spoilage and biodeterioration of a large 38 variety of foods and feedstuffs. Various genera such as Aspergillus, Cladosporium, Alternaria or

39 Penicillium are involved in different food spoilage (Pitt \& Hocking 1997). Penicillium is one of the 40 most widespread fungal genera isolated from food products and, in addition to the economic losses

41 they cause, several Penicillium species may produce mycotoxins that represent a potential health 42 risk for humans and animals (Pitt \& Hocking 1997; Samson et al. 2004). Numerous intrinsic 43 parameters in foods (water activity, $\mathrm{pH}$, preservatives, etc.) or extrinsic ones (temperature, 44 atmosphere composition, etc.) provide favourable conditions for moulds to develop. Changes in 45 these parameters beyond the tolerated range may represent a potential source of stress that can 46 affect germination, mycelial growth, conidiation or even synthesis of secondary metabolites as 47 mycotoxins (Espeso et al. 1993; Calvo et al. 2002; Magan et al. 2002; Schmidt-Heydt et al. 2008).

48 Nevertheless, to our knowledge, little is known about the effects of shock conditions on the growth 49 and physiology of food related filamentous fungi. Understanding these effects in spoilage moulds 50 would be useful for a better risk management of alteration and toxicity of food products. In this 51 study, investigations were conducted on Penicillium glabrum, which is very frequently encountered 
52 in the food processing industry due to its ubiquitous presence in the environment and its capacity to

53 disperse a large number of spores into the air (Pitt \& Hocking 1997). This fungal contaminant was

54 has been isolated in a large variety of products, including cheese (Hocking \& Faedo 1992), nuts

55 (Freire et al. 2000), bottled mineral water (Cabral \& Fernandez Pinto 2002), etc. In our study, the

56 effects of thermal and $\mathrm{pH}$ shock conditions were investigated in $P$. glabrum grown in liquid

57 cultures. Temperature was chosen for this study because it is one of the most important factors that

58 determine the ability of moulds to grow (Dantigny et al. 2005). pH was also investigated as this is a

59 main environmental factor of physiological importance that can vary significantly depending on the

60 food product. Shock conditions are usually defined by their intensity and their duration. To

61 efficiently study the physiological effect of a large range of these two environmental shock

62 conditions, we analysed P. glabrum growth using the response surface methodology (RSM) (Myers

63 et al. 1989). A two-factorial central composite design (CCD) (Box et al. 1978) was applied to

64 determine 'optimised' experimental shock conditions by combining different stress intensities and

65 durations for each factor studied. Results from CCD were used to modelise the effects of shock

66 intensity and duration on the measured response (fungal biomass growth).

67 This study brings a missing characterisation of the growth response of a fungal food contaminant to

68 different thermal, acidic and alkaline conditions. Such results were needed to support the choice of

69 temperature and $\mathrm{pH}$ shock conditions to investigate stress response of $P$. glabrum.

\section{Materials and methods}

\section{Fungal strain and culture medium}

73 The fungal strain used in this study was isolated from contaminated, aromatised mineral water. It

74 was characterised as Penicillium glabrum (Wehmer) Westling according to the reference method

75 for classifying Penicillium species based on morphological characteristics (Pitt, 1988). To confirm

76 the morphological identification of the fungal strain, we sequenced the internal transcribed spacer

77 region including the $5.8 \mathrm{~S}$ of the ribosomal gene in both directions after PCR amplification. Species 
identification was confirmed based on the results of BLAST (Basic Local Alignments Search Tool)

79 searches against known sequences in the GenBank database using BLASTn. The strain has been

80 registered as LMSA 1.01.421 in the Brittany Microbe Culture Collection (Souchothèque de

81 Bretagne; University of Brest, France; www.ifremer.fr/souchotheque) and as LCP 08.5568 in the

82 fungal collection of the Laboratory of Cryptogamy at the Museum National d'Histoire Naturelle

83 (Paris, France; www.mnhn.fr). The cardinal (minimum, optimum and maximum) growth conditions

84 of temperature and $\mathrm{pH}$ for this filamentous fungus have been estimated to be $6.6{ }^{\circ} \mathrm{C}, 24.3{ }^{\circ} \mathrm{C}$ and

$8533.8^{\circ} \mathrm{C}$ and $\mathrm{pH} 0.50-1.00$, pH 5.50 and pH 11.20 (Nevarez et al. 2009).

86 For strain maintenance and collection of spores, the strain was cultured in tubes of potato dextrose

87 agar medium (PDA, Difco Laboratories, Detroit, MI, USA) at $25^{\circ} \mathrm{C}$. The $\mathrm{pH}$ of this culture 88 medium was 5.00 .

\section{Shock application on $\boldsymbol{P}$. glabrum liquid cultures}

91 Spores were collected from seven-day-old mycelium by flooding each tube with $2 \mathrm{ml}$ of sterile

92 water containing $0.01 \%$ of Tween 80 (Sigma-Aldrich, Saint Louis, MO, USA) under agitation at

$93250 \mathrm{rpm}$. Mycelia were cultured from a suspension of $5 \times 10^{6} \mathrm{P}$. glabrum spores inoculated into a

$94250 \mathrm{ml}$ Erlenmeyer flask containing $50 \mathrm{ml}$ of potato dextrose broth medium (PDB, Difco

95 Laboratories). Cultures of $P$. glabrum were first grown in standard PDB $(\mathrm{pH}=5.0)$ at $25^{\circ} \mathrm{C}$,

$96120 \mathrm{rpm}$ for $48 \mathrm{~h}$ and then subjected to different experimental conditions. To test response to a

97 range of thermal conditions, mycelia were aseptically filtered at room temperature and transferred

98 immediately into $50 \mathrm{ml}$ of standard PDB media and incubated at different temperature conditions at

$99120 \mathrm{rpm}$. For efficient incubation, each inoculated medium had been previously warmed to its

100 corresponding experimental temperature. To test response to $\mathrm{pH}$ conditions, mycelia grown for $48 \mathrm{~h}$

101 were aseptically filtered and transferred into modified PDB medium at different $\mathrm{pH}$ values. Each

102 medium was prepared with PDB and to stabilise the $\mathrm{pH}$, appropriate buffers were added: citrate-

103 phosphate buffer for $\mathrm{pH}$ from 2.00 to 8.00 , borate buffer for $\mathrm{pH}$ from 8.00 to 9.50 , CAPS (N- 
104 cyclohexyl-3-aminopropanesulfonic acid) buffer for $\mathrm{pH} 9.50$ from to 11.50. For marginal $\mathrm{pH}$

105 conditions above $\mathrm{pH} 11.50$ or below $\mathrm{pH} 2.00$, buffer was not required for $\mathrm{pH}$ stability. The $\mathrm{pH}$ was 106 then adjusted with $\mathrm{NaOH}$ and $\mathrm{HCl}(1,2$ or $10 \mathrm{M})$. The $\mathrm{pH}$ of each adjusted PDB was verified. The 107 media were filtered through a $0.22 \mu \mathrm{m}$ membrane and $50 \mathrm{ml}$ was aseptically distributed into sterile $108250 \mathrm{ml}$ Erlenmeyer flasks.

109 The $\mathrm{pH}$ of each adjusted medium was assessed after fungal culture and variation observed in each 110 medium before inoculation was less than $0.5 \mathrm{pH}$ units. These results confirmed the efficiency of the 111 various buffers used to prepare the adjusted media.

112 After incubation under thermal or $\mathrm{pH}$ experimental conditions, the mycelia were aseptically filtered 113 at room temperature and transferred into standard PDB medium ( $\mathrm{pH}$ 5.00) for cultivation in optimal 114 conditions for $48 \mathrm{~h}$ at $25^{\circ} \mathrm{C}, 120 \mathrm{rpm}$. Mycelia were then filtered, washed thoroughly with distilled 115 water, dried at $70{ }^{\circ} \mathrm{C}$ for $48 \mathrm{~h}$ and weighed with a precision balance. Mycelium growth was 116 obtained by quantifying the mycelium dry mass.

117 Other than the experimental cultures of $P$. glabrum for each tested environmental factor 118 (temperature, $\mathrm{pH}$ ), two sets of control 'unstressed' mycelia were also cultured under optimum 119 conditions at $25{ }^{\circ} \mathrm{C}$. The first control, T48, was early-harvested after $48 \mathrm{~h}$ of culture and the dry 120 biomass obtained was used as the minimum fungal growth reached by each culture before 121 application of experimental thermal and $\mathrm{pH}$ conditions. A second control, T96, was harvested after $12296 \mathrm{~h}$ culture and corresponded to $48 \mathrm{~h}$ of culture under optimum conditions in standard PDB at 25 $123{ }^{\circ} \mathrm{C}$ and then aseptically filtered and transfered to standard PDB at $25^{\circ} \mathrm{C}$ for another $48 \mathrm{~h}$. The dry 124 fungal biomass obtained for this control was considered as the fungal growth after $96 \mathrm{~h}$ culture in 125 optimum conditions. The growth results obtained for each temperature or $\mathrm{pH}$ condition were 126 expressed as the relative growth rate, in percent. This is the ratio between the fungal dry weight 127 obtained under a given experimental condition and the fungal dry weight obtained in the control 128 T96.

129 Experimental design and statistical analysis 
130 The thermal and $\mathrm{pH}$ stress experiments were conducted according to a two-factorial central

131 composite design (Box et al. 1978) (Fig 1). For each of the three applied stresses (thermal, acid and

132 alkali stress), the CCD (Factors/Blocks/Runs $=2 / 1 / 11$ ) defined nine experimental conditions by

133 varying the intensity of the tested environmental factor and its duration (Table 1). Given the

134 biological variability of $P$. glabrum growth, each experimental point was replicated three times to

135 increase precision (consequently, central conditions of each CCD were replicated nine times) and

136 median values of those three replicates were considered. The growth results obtained for thermal,

137 acid or alkali stress experiments were analysed separately using STATISTICA 8 (StatSoft) and a

138 response surface was determined to model the effect of different stress on P. glabrum growth. The

139 growth results of both controls (T48 and T96) were also reported in the response surface for

140 comparison with CCD results.

141 For $\mathrm{pH}$ investigations, another experimental design was also implemented. Twenty $\mathrm{pH}$ values were

142 studied in a large range from 0.15 to 12.50 with a single duration of $240 \mathrm{~min}$. To obtain better

143 estimates, four replicates were studied for each experimental condition. The results obtained were

144 analysed with STATGRAPHICS 5.0 (Statistical Graphics Corp) using a one-way ANOVA and the

145 LSD test to determine which fungal growths were significantly different depending on the tested $\mathrm{pH}$

146 condition. For each condition, means, (which were very close to median values) were plotted and

147 LSD results were reported by assigning letters to the means. Means with the same letter are not 148 statistically different $(\mathrm{P}>0.05)$.

\section{Results}

151 Effect of thermal shock on fungal growth

152 To investigate the effect of temperature on Penicillium glabrum growth, two-factorial CCD and 153 RSM were used. Temperature and exposure duration varied respectively from 30 to $50{ }^{\circ} \mathrm{C}$ and from $15410 \mathrm{~min}$ to $230 \mathrm{~min}$. The low, middle and high levels of both variables were determined from 155 preliminary experiments on fungal growth (unpublished data). 
P. glabrum growth results obtained using a CCD were statistically analysed and both parameters

157 (temperature level and exposure time) and their interaction had significant effects $(P<0.05)$ on

158 fungal growth. A response surface was determined from the results (Fig 2) and the goodness-of-fit

159 between the predicted values and the experimental data was very high (Fig 3), giving a coefficient

160 of determination $\left(\mathrm{R}^{2}\right)$ of 0.98 , indicating a very good adjustment of the model with experimental

161 data.

162 Inspection of the response surface showed that increasing temperature and exposure time affect $P$.

163 glabrum growth in a gradual manner.

164 The adjusted surface response (Fig 2), showed three distinct response areas delimited by the results of both growth controls T96 and T48 (which was $48 \%$ of T96). The first response area was observed for the less intense thermal shock conditions $30{ }^{\circ} \mathrm{C}: 120 \mathrm{~min}$ to $40{ }^{\circ} \mathrm{C}: 10 \mathrm{~min}$ and revealed an increase of fungal growth in comparison with the fungal biomass of the control T96. A clear fungal growth increase was measured for the lowest shock condition $\left(30^{\circ} \mathrm{C}: 120 \mathrm{~min}\right)$ at supraoptimal temperature (Nevarez et al. 2009). A second area was observed for intermediate thermal conditions $\left(40^{\circ} \mathrm{C}: 230 \mathrm{~min}, 40^{\circ} \mathrm{C}: 120 \mathrm{~min}\right.$ or $\left.47^{\circ} \mathrm{C}: 42 \mathrm{~min}\right)$, which showed a moderate reduction in

171 fungal biomass compared to the T96 control but still greater than the fungal growth of the T48 172 control. The third area was observed for the highest thermal conditions, e.g. $47^{\circ} \mathrm{C}: 198$ min or 50 $173{ }^{\circ} \mathrm{C}: 120 \mathrm{~min}$, and revealed a strong decrease in $P$. glabrum growth. Fungal biomass values were 174 even lower than those of the T48 control.

175 Considering the fungal growth results, thermal conditions as $40{ }^{\circ} \mathrm{C}: 120 \mathrm{~min}, 40{ }^{\circ} \mathrm{C}: 230 \mathrm{~min}$ or 47 $176{ }^{\circ} \mathrm{C}: 42 \mathrm{~min}$, appeared to affect moderately $P$. glabrum growth.

\section{Effect of pH shock on fungal growth}

179 Statistical analysis of the results obtained using a CCD for acid and alkali $\mathrm{pH}$ indicated that 180 exposure time had no significant effect $(P>0.05)$ on fungal growth for the range of values tested $(10$ 181 to $230 \mathrm{~min}$ ) (data not shown). This result precluded 2D analysis and response surface modelling, 
182 since only one of the two tested variables ( $\mathrm{pH}$ value) had a significant influence. Consequently, we

183 modified our experimental design by using a monofactorial experimental procedure on a large range

184 of $\mathrm{pH}$ from 0.15 to 12.50 for a single exposure time of $240 \mathrm{~min}$.

185 Global inspection of the results (Fig 4) shows that P. glabrum is able to grow relatively well after $186240 \mathrm{~min}$ of exposure in a very wide range of $\mathrm{pH}$ conditions, spanning $\mathrm{pH} 2.00$ to 11.50.

187 Analysis of fungal growth clearly showed four distinct areas of response over the wide range of $\mathrm{pH}$ 188 conditions tested. The first area was observed for $\mathrm{pH} 2.00$ to 7.00 , which had a very low influence 189 on fungal growth (80-100\% of T96 growth). The second area was observed for alkaline conditions, 190 from $\mathrm{pH} 8.00$ to 11.50 , which induced a decrease in fungal growth, showing a growth rate of 60$19170 \%$ of T96 growth.

192 The third and fourth response areas were observed for very acidic conditions ( $\mathrm{pH} 0.15$ to 1.00) or 193 alkaline conditions ( $\mathrm{pH} 12.00$ to 12.50). These conditions induced a dramatic decrease in fungal 194 growth after 240 min of exposition. The fungal biomass values were even lower than the control 195 T48 value.

196 Considering the fungal growth results obtained, alkaline shock conditions between $\mathrm{pH} 8.00$ to 11.50 197 for 240 min duration affect significantly and moderately $P$. glabrum development. Concerning 198 acidic shock, the transition from no detrimental to detrimental effect appears very steep.

\section{Discussion}

201 To investigate the effect of temperature and $\mathrm{pH}$ shocks on Penicillium glabrum growth, two202 factorial CCD and RSM were employed. Using a CCD offers the possibility to assess the effect of a 203 large range of conditions by testing a limited and optimised number of experimental points with a 204 low number of replicates. This approach has been successfully employed in fungi to examine 205 chitinase regulation (Lopes et al. 2008), to study the influence of environmental factors such as 206 temperature and $\mathrm{pH}$ on the growth of the fermenting yeast Pachysolen tannophilus used in 
207 industrial fermentation processes (Roebuck et al. 1995) or to investigate the influence of

208 temperature, $\mathrm{pH}$ and $\mathrm{a}_{\mathrm{w}}$ on yeast to study their antagonistic properties (Sinigaglia et al. 1998). RSM

209 is a well-known method for optimising for example medium composition or other critical variables

210 that affect for example enzyme production or microbial growth. This study used RSM to predict

211 fungal growth anywhere within the limits of the experimentally tested environmental factors. The

212 quadratic model obtained in those conditions permitted suitable predictions.

213 Regarding temperature, inspection of the response surface clearly shows that increasing temperature

214 and exposure duration affect $P$. glabrum growth in a gradual manner. The influence of a given

215 temperature in a wide range of exposure duration has been also observed in Saccharomyces

216 cerevisiae exposed to $37^{\circ} \mathrm{C}$ for $15,30,45,60,120,240$ and $480 \mathrm{~min}$ (Sakaki et al. 2003).

217 The less intense shock condition $\left(30^{\circ} \mathrm{C}: 120 \mathrm{~min}\right)$ did not reduce $P$. glabrum fungal growth, but

218 showed an unexpected increase in fungal biomass. This result suggests that when a fungal

219 contaminant such as $P$. glabrum is exposed to relatively weak stress conditions, its development on

220 food products may be enhanced. This observation could be practically important for food industry.

221 The intermediate stress conditions $\left(40^{\circ} \mathrm{C}: 120 \mathrm{~min}, 40^{\circ} \mathrm{C}: 230 \mathrm{~min}, 47^{\circ} \mathrm{C}: 42 \mathrm{~min}\right)$ induced more or

222 less moderate fungal biomass reductions which can be attributed simultaneously to growth

223 reduction or increased lag time for growth due to thermal shock. This fungal growth reduction

224 could be explained by a variety of cellular effects corresponding with thermal stress. It is known

225 that elevated temperature can affect: (i) the structure of proteins, possibly modifying their biological

226 activity and overall cellular functioning; (ii) the biosynthesis of a large number of ubiquitous

227 proteins which decrease or are completely stopped (Plesofsky-Vig \& Brambl 1987; Curle \& Kapoor

228 1988); and (iii) plasma membrane fluidity (Beney \& Gervais 2001). As described in S. cerevisiae,

229 an increase of plasma membrane permeability can affect cellular integrity and metabolism (Guyot et

230 al. 2005).

231 Finally, in more drastic thermal conditions $\left(47^{\circ} \mathrm{C}: 198 \mathrm{~min}, 50^{\circ} \mathrm{C}: 120 \mathrm{~min}\right)$, the fungal biomass 232 decreased compared to the initial fungal biomass (T48) before applying the experimental stress 
conditions. According to the literature, this decrease can be explained by fungal lysis (Emri et al.

234 2004; Koutinas et al. 2005) or may be due to an ordered degradation of cellular reserves (McNeil et

235 al. 1998). In yeast and filamentous fungi, autolysis can be characterised by a fungal biomass

236 decline. Autolysis occurs in response to a wide range of extrinsic factors such as heat, chemical

237 treatment, nutrient starvation, etc., which may induce the loss of membrane function leading to a

238 breakdown in intracellular compartimentalisation and the release of lytic enzymes responsible of

239 macromolecular degradation (Hernawan \& Fleet 1995; McNeil et al. 1998). Important reduction in

240 fungal growth under high temperatures such as $50{ }^{\circ} \mathrm{C}$ has also been reported in S. cerevisiae (Seppa

241 et al. 2004) and Neurospora crassa (Plesofsky-Vig \& Brambl 1985), for which optimum growth

242 conditions are $25^{\circ} \mathrm{C}$ and $30^{\circ} \mathrm{C}$, respectively. The yeast Candida albicans, for which optimum

243 growth temperature is $37^{\circ} \mathrm{C}$, is also very affected by exposure at $55^{\circ} \mathrm{C}$ (Zeuthen \& Howard 1989 ).

244 In our case, thermal conditions of $47^{\circ} \mathrm{C}: 198 \mathrm{~min}$ or $50^{\circ} \mathrm{C}: 120 \mathrm{~min}$ appeared to affect not only $P$.

245 glabrum fungal growth but also proteins and mRNA integrity. In fact, subjecting total proteins to

246 electrophoresis showed that most of the proteins observed in the T96 control condition were not

247 visible in the highest stress conditions mentioned above (data not shown). Moreover, we analysed

248 the total RNA using electrophoretic RNA separation on microfabricated chips to determine their

249 quality. In the drastic growth conditions, this analysis revealed a decrease in the $18 \mathrm{~S}$ and $28 \mathrm{~S}$

250 ribosomal RNA peaks and an increase in smaller, intermediate RNA fragments, indicating

251 substantial total RNA degradation (Nevarez et al. 2008).

252 Given the results on fungal growth, thermal conditions such as $40^{\circ} \mathrm{C}: 120 \mathrm{~min}, 40^{\circ} \mathrm{C}: 230 \mathrm{~min}$ or

$25347^{\circ} \mathrm{C}: 42 \mathrm{~min}$, appeared to moderately, but significantly affect $P$. glabrum growth. These conditions

254 may therefore be appropriate for further investigations on stress response. In addition, these thermal

255 shock conditions (temperature level and exposure time) correspond pretty well with those used in

256 other thermal stress studies conducted in fungi which are unfrequently justified. For example, a

257 study was realised in S. cerevisiae in order to isolate heat shock proteins (HSP), HSP 82 and HSP

258104 by shifting optimal cultures from $25{ }^{\circ} \mathrm{C}$ to $39{ }^{\circ} \mathrm{C}$ for $1 \mathrm{~h}$ (Sanchez et al. 1993). Other 
investigations conducted in $N$. crassa or $C$. albicans exposed fungi to experimental conditions from

$26030{ }^{\circ} \mathrm{C}$ to $45^{\circ} \mathrm{C}$ for $90 \mathrm{~min}$ and from $37^{\circ} \mathrm{C}$ to $40-46{ }^{\circ} \mathrm{C}$ for $30 \mathrm{~min}$, respectively (Plesofsky-Vig \&

261 Brambl 1985; Zeuthen \& Howard 1989). Thermal stress was also investigated with a transcriptional

262 approach using microarrays in yeasts S. cerevisiae or Schizosaccharomyces pombe, from $25^{\circ} \mathrm{C}$ to

$26337^{\circ} \mathrm{C}$ for $2 \mathrm{~h}$ or $30^{\circ} \mathrm{C}$ to $39^{\circ} \mathrm{C}$ for $1 \mathrm{~h}$, respectively (Causton et al. 2001; Chen et al. 2003). In our

264 case, where physiological experimental stress conditions were being validated, the thermal

265 condition of $40^{\circ} \mathrm{C}: 120$ min was employed as central condition to investigate heat shock response at

266 the transcriptional level (Nevarez et al. 2008). A transcriptional study combining suppression-

267 subtraction hybridisation and cDNA microarrays has been conducted in this fungus to isolate

268 differentially expressed genes in response to thermal shock. Of the various isolated genes, a few are

269 down-regulated and encode for proteins involved in general cellular metabolism. Given this thermal

270 shock condition, gene down-regulation may explain the $P$. glabrum growth reduction as observed in

271 this study.

272 The effect of a very large range of $\mathrm{pH}$ conditions was tested on P. glabrum growth for a single 273 exposure time of $240 \mathrm{~min}$. High $\mathrm{pH}$ tolerance has been already described in many filamentous fungi 274 which appear to be little affected by changes in culture $\mathrm{pH}$ (Wheeler et al. 1991). Many Penicillium 275 species including $P$. chrysogenum, $P$. camemberti, $P$. aurantiogriseum, $P$. marneffei, $P$. crustosum 276 or $P$. islandicum are able to grow from $\mathrm{pH} 3.00-4.00$ to $9.00-10.00$ (Wheeler et al. 1991;

277 Thompson et al. 1993; Cao et al. 2007). The ability of fungi to develop in a wide range of $\mathrm{pH}$ is 278 partially due to adaptation associated with a genetic regulatory system that tailors gene expression 279 to the ambient $\mathrm{pH}$ (Arst \& Penalva 2003). Considerable progress has been made in characterising 280 fungal genetic $\mathrm{pH}$ regulatory systems because they are important for major processes including 281 pathogenesis and the production of extracellular enzymes, penicillin or mycotoxins (Espeso et al. 282 1993; Denison 2000). Various pH regulatory systems have been described in fungi (Aspergillus 283 nidulans, A. niger, Penicillium chrysogenum, S. cerevisiae, C. albicans, Yarrowia lipolytica; 284 Denison 2000; Arst \& Penalva 2003). 
285 In acidic conditions ( $\mathrm{pH} 2.00$ to 7.00 ), fungal growth was only slightly affected. This observation is

286 in accordance with reports that most filamentous fungi including Aspergillus spp., Fusarium spp.

287 and Penicillium spp. show high tolerance to acidic media and their optimum growth is around $\mathrm{pH}$

2885.50 - 6.00 (Deacon 2006). Similar observations have been made on several Penicillium species

289 such as P. citreonigrum, P. jensenii or P. roqueforti (Sacks et al. 1986; Wheeler et al. 1991; Gock et

290 al. 2003). It has also been shown in S. cerevisiae that yeast cells grow more rapidly in acidic media

291 than in neutral or alkaline media (Lamb et al. 2001). An important factor for the maintenance of an

292 acidic environment is the yeast plasma membrane $\mathrm{H}^{+}$-ATPase, which actively extrudes protons and

293 imports many nutrients and cations (Serrano et al. 2002).

294 The alkaline $\mathrm{pH}$ conditions ( $\mathrm{pH} 8.00$ to 11.50) induced a greater growth decrease area than

295 observed in acidic conditions. This effect may be explained by some cellular modifications caused

296 by alkaline $\mathrm{pH}$. In $S$. cerevisiae for example, it has been shown that alkaline media induce

297 disruption of membrane proton gradients that normally supply energy for nutrient and ion transport

298 essential for fungal development (Lamb et al. 2001). Some authors also report in S. cerevisiae a

299 significant repression of genes involved in amino acid or purine biosynthesis and in carbohydrate

300 metabolism that could explain limitation of yeast growth (Serrano et al. 2002). These authors

301 suggest that copper or iron availability and solubility can be reduced by alkaline $\mathrm{pH}$, which could

302 affect some enzymatic activities. Thus, highly alkaline environments can be considered as stressing

303 conditions.

304 Given the results on fungal growth, alkaline stress conditions between $\mathrm{pH} 8.00$ to 11.50 for $240 \mathrm{~min}$

305 may be appropriate for further investigations on stress response as they seemed to moderately, but

306 significantly affect fungal development. On the basis of our results, the experimental point $\mathrm{pH}$

307 9.00:240 min may be employed as central condition for further studies in P. glabrum. Comparable

308 alkaline $\mathrm{pH}$ conditions have also been used in several studies on fungi as, for example, in $C$.

309 glabrata to analyse its $\mathrm{pH}$ response by transferring cultures from $\mathrm{pH} 4.00$ to $\mathrm{pH} 8.00$ (Schmidt et al.

310 2008). Some molecular studies have been also conducted at pH 4.00 to 8.00 in C. albicans or A. 
311 nidulans to investigate the role of $\mathrm{pH}$ transcription factors (Rim13p and PacC respectively) (Espeso

$312 \&$ Arst 2000; Li et al. 2004). A transcriptional approach using microarrays has been employed in $S$.

313 cerevisiae at $\mathrm{pH}$ ranging from 6.00 to 7.90 (Causton et al. 2001).

314 Finally, in extreme $\mathrm{pH}$ conditions ( $\mathrm{pH} 0.15$ to 1.00 and $\mathrm{pH} 12.00$ to 12.50 ), a great decrease in

315 fungal biomass was induced. These drastic conditions severely affected cellular metabolism. As

316 suggested for thermal stress, the effect induced by these conditions on P. glabrum growth may be

317 also explained by fungal autolysis (McNeil et al. 1998).

318 In summary, the present work investigated a wide range of temperature and $\mathrm{pH}$ conditions to 319 analyse their effect on $P$. glabrum growth to determine 'optimised' experimental shock conditions.

320 To our knowledge, this approach has not been previously reported in other fungal stress studies, 321 which generally use a limited number of experimental conditions. The results obtained here made it 322 possible to determine experimental conditions that may be potentially appropriate for further 323 investigations on stress response. Based on our results, we propose that conditions such as $32440^{\circ} \mathrm{C}: 120 \mathrm{~min}, \mathrm{pH}$ 1.50:240 $\mathrm{min}$ or $\mathrm{pH}$ 9.00:240 min, can be used to produce a physiological stress 325 response because they moderately, but significantly affect growth in P. glabrum.

\section{Acknowledgements}

329 This entire study was carried out with financial support from the Brittany Regional Council.

\section{REFERENCES}

332 Arst Jr HN, Penalva MA, 2003. pH regulation in Aspergillus and parallels with higher eukaryotic 333 regulatory systems. Trends in Genetics 19: 224-231.

334 Beney L, Gervais P, 2001. Influence of the fluidity of the membrane on the response of 335 microorganisms to environmental stresses. Applied Microbiology and Biotechnology 57: 34-42. 
336 Box GEP, Hunter WG, Hunter JS, 1978. Statistics for experimenters. An introduction to design data 337 analysis and model buildings. Wiley, New York.

338 Cabral D, Fernandez Pinto VE, 2002. Fungal spoilage of bottled mineral water. International 339 Journal of Food Microbiology 72: 73-76.

340 Calvo AM, Wilson RA, Bok JW, Keller NP, 2002. Relationship between secondary metabolism and 341 fungal development. Microbiology and Molecular Biology Reviews 66: 447-59.

342 Cao C, Li R, Wan Z, Liu W, Wang X, Qiao J, Wang D, Bulmer G, Calderone R, 2007. The effects 343 of temperature, $\mathrm{pH}$, and salinity on the growth and dimorphism of Penicillium marneffei. Medical 344 Mycology 45: 401-407.

345 Causton HC, Ren B, Koh SS, Harbison CT, Kanin E, Jennings EG, Lee TI, True HL, Lander ES, 346 Young RA, 2001. Remodeling of yeast genome expression in response to environmental changes. 347 Molecular Biology of the Cell 12: 323-337.

348 Chen D, Toone WM, Mata J, Lyne R, Burns G, Kivinen K, Brazma A, Jones N, Bahler J, 2003. 349 Global transcriptional responses of fission yeast to environmental stress. Molecular Biology of the 350 Cell 14: 214-229.

351 Curle CA, Kapoor M, 1988. Expression of heat shock genes of Neurospora crassa: effect of 352 hyperthermia and other stresses on mRNA levels. Biochemistry and Cell Biology 66: 81-92.

353 Dantigny P, Guilmart A, Bensoussan M, 2005. Basis of predictive mycology. International Journal 354 of Food Microbiology 100: 187-196. 
Deacon J, 2006. Fungal Biology, 4th edition. Blackwell Publishing, Oxford, UK.

356 Denison SH, 2000. pH regulation of gene expression in fungi. Fungal Genetics and Biology 29: 61$357 \quad 71$.

358 Espeso EA, Arst Jr HN, 2000. On the mechanism by which alkaline pH prevents expression of an 359 acid-expressed gene. Molecular and Cellular Biology 20: 3355-3363.

360 Espeso EA, Tilburn J, Arst Jr HN, Penalva MA, 1993. pH regulation is a major determinant in 361 expression of a fungal penicillin biosynthetic gene. EMBO Journal 12: 3947-3956.

362 Emri T, Molnar Z, Pusztahelyi T, Rosen S, Pocsi I, 2004. Effect of vitamin E on autolysis and 363 sporulation of Aspergillus nidulans. Applied Biochemistry and Biotechnology 118: 337-348.

365 Freire FC, Kozakiewicz Z, Paterson RR, 2000. Mycoflora and mycotoxins in Brazilian black 366 pepper, white pepper and Brazil nuts. Mycopathologia 149: 13-19.

367 Gock MA, Hocking AD, Pitt JI, Poulos PG, 2003. Influence of temperature, water activity and pH 368 on growth of some xerophilic fungi. International Journal of Food Microbiology 81: 11-19.

369 Guyot S, Ferret E, Gervais P, 2005. Responses of Saccharomyces cerevisiae to thermal stress.

370 Biotechnology and Bioengineering 92: 403-409.

371 Hernawan T, Fleet G, 1995. Chemical and cytological changes during the autolysis of yeasts.

372 Journal of Industrial Microbiology 14: 440-450.

373 Hocking AD, Faedo M, 1992. Fungi causing thread mould spoilage of vacuum packaged Cheddar 
374 cheese during maturation. International Journal of Food Microbiology 16: 123-130.

375 Koutinas AA, Wang RH, Webb C, 2005. Development of a process for the production of nutrient 376 supplements for fermentations based on fungal autolysis. Enzyme and Microbial Technnology 36: 377 629-638.

378 Lamb TM, Xu W, Diamond A, Mitchell AP, 2001. Alkaline response genes of Saccharomyces 379 cerevisiae and their relationship to the RIM101 pathway. Journal of Biological Chemistry 276: $380 \quad 1850-1856$.

381 Li M, Martin SJ, Bruno VM, Mitchell AP, Davis DA, 2004. Candida albicans Rim13p, a protease 382 required for Rim101p processing at acidic and alkaline pHs. Eukaryotic Cell 3: 741-751.

383 Lopes MA, Gomes DS, Bello Koblitz MG, Pirovani CP, Cézar De Mattos Cascardo J, Goes-Neto 384 A, Micheli F, 2008. Use of response surface methodology to examine chitinase regulation in the 385 basidiomycete Moniliophthora perniciosa. Mycological Research 112: 399-406.

386 Magan N, Hope R, Colleate A, Baxter ES, 2002. Relationship between growth and mycotoxin 387 production by Fusarium species, biocides and environment. European Journal of Plant Pathology 388 108: 685-690.

389 McNeil B, Berry DR, Harvey LM, Grant A, White S, 1998. Measurement of autolysis in submerged 390 batch cultures of Penicillium chrysogenum. Biotechnology and Bioengineering 57: 297-305.

391 Myers RH, Khuri AI, Carter WH, 1989. Response surface methodology: 1966-1988. Technometrics 392 32: 137-157. 
393 Nevarez L, Vasseur V, Le Dréan G, Tanguy A, Guisle-Marsollier I, Houlgatte R, Barbier G, 2008.

394 Isolation and analysis of differentially expressed genes in Penicillium glabrum subjected to thermal 395 stress. Microbiology 154: 3752-3765.

396 Nevarez L, Vasseur V, Le Madec A, Le Bras MA, Coroller L, Leguérinel I, Barbier G, 2009.

397 Physiological traits of Penicillium glabrum strain LCP 08.5568, a filamentous fungus isolated from 398 bottled aromatised mineral water. International Journal of Food Microbiology 130: 166- 171.

399 Pitt JI, 1988. A laboratory guide to commun Penicillium species, Second edition. Food Science 400 Australia.

401 Pitt JI, Hocking AD, 1997. Fungi and food spoilage, Second edition. London : Blackie Academic 402 and Professional.

403 Plesofsky-Vig N, Brambl R, 1985. Heat shock response of Neurospora crassa: protein synthesis 404 and induced thermotolerance. Journal of Bacteriology 162: 1083-1091.

405 Plesofsky-Vig N, Brambl R, 1987. Two developmental stages of Neurospora crassa utilize similar 406 mechanisms for responding to heat shock but contrasting mechanisms for recovery. Molecular and 407 Cellular Biology 7: 3041-3048.

408 Roebuck K, Brundin A, Johns M, 1995. Response surface optimization of temperature and $\mathrm{pH}$ for 409 the growth of Pachysolen tannophilus. Enzyme and Microbial Technology 17: 75-78.

410 Sacks LE, King AD Jr, Schade JE, 1986. A note of pH gradient plates for fungal growth studies. 411 Journal of Applied Bacteriology 61: 235-238. 
412 Sakaki K, Tashiro K, Kuhara S, Mihara K, 2003. Response of genes associated with mitochondrial

413 function to mild heat stress in yeast Saccharomyces cerevisiae. Journal of Biochemistry (Tokyo)

414 134: 373-384.

415 Samson RA, Hoekstra ES, Frisvad JC, Filtenborg O, 2004. Introduction to food and airborne fungi,

416 seventh edition. Centraalbureau voor Schimmelcultures (CBS), Utrecht, Netherlands.

417 Sanchez Y, Parsell DA, Taulien J, Vogel JL, Craig EA, Lindquist S, 1993. Genetic evidence for a

418 functional relationship between Hsp104 and Hsp70. Journal of Bacteriology 175: 6484-6491.

419 Schmidt P, Walker J, Selway L, Stead D, Yin Z, Enjalbert B, Weig M, Brown AJ, 2008. Proteomic 420 analysis of the $\mathrm{pH}$ response in the fungal pathogen Candida glabrata. Proteomics 8: 534-544.

421 Schmidt-Heydt M, Magan N, Geisen R, 2008. Stress induction of mycotoxin biosynthesis genes by 422 abiotic factors. FEMS Microbiology Letters 284: 142-149.

423 Seppa L, Hanninen AL, Makarow M, 2004. Upregulation of the Hsp104 chaperone at physiological 424 temperature during recovery from thermal insult. Molecular Microbiology 52: 217-25.

425 Serrano R, Ruiz A, Bernal D, Chambers JR, Arino J, 2002. The transcriptional response to alkaline $426 \mathrm{pH}$ in Saccharomyces cerevisiae: evidence for calcium-mediated signalling. Molecular 427 Microbiology 46: 1319-1333.

428 Sinigaglia M, Corbo MR, Ciccarone C, 1998. Influence of temperature, $\mathrm{pH}$ and water activity on 429 "in vitro" inhibition of Penicillium glabrum (Wehmer) Westling by yeasts. Microbiological 430 Research 153: 137-143. 
431 Thompson DP, Metevia L, Vessel T, 1993. Influence of $\mathrm{pH}$ alone and in combination with phenolic 432 antioxidants on growth and germination of mycotoxigenic species of Fusarium and Penicillium. 433 Journal of Food Protection 56: 134-138.

434 Wheeler KA, Hurdman BF, Pitt JI, 1991. Influence of $\mathrm{pH}$ on the growth of some toxigenic species 435 of Aspergillus, Penicillium and Fusarium. International Journal of Food Microbiology 12: 141436149.

437 Zeuthen ML, Howard DH, 1989. Thermotolerance and the heat-shock response in Candida 438 albicans. Journal of General Microbiology 135: 2509-2518. 